Open Access

\title{
The Chinese herb-derived Sparstolonin B suppresses HIV-1 transcription
}

\author{
Xin Deng, Yaping Zhang, Feng Jiang, Ran Chen, Peichun Peng, Bin Wen and Jian Liang*
}

\begin{abstract}
Background: The Chines herb derived Sparstolonin B, $(S \operatorname{snB})$, is a recently identified natural compound that selectively blocks TLR2- and TLR4-mediated inflammatory signaling. But it is unknown whether this compound has any effect on HIV infection.

Findings: We found that SSnB treatment blocked HIV-1 transcription via a novel mechanism that requires the TAR region. Treatment of human T cell lines or peripheral blood mononuclear cells with SsnB at $1 \mu \mathrm{M}$ significantly inhibited HIV production. Lastly, SsnB was able to inhibit HIV in synergy with AZT.

Conclusions: These data suggest that SsnB is a novel natural compound that inhibits HIV-1 transcription and may be a new drug in the treatment of HIV infection.
\end{abstract}

Keywords: Sparstolonin B, HIV transcription, TAR region

\section{Findings}

Despite the success of highly active antiretroviral therapy (HAART) in containing human immunodeficiency virus (HIV) infection, there has been an urgent demand for cheaper and alternative drugs in developing countries. Moreover, HIV persists in stable reservoirs harboring chromosomally integrated latent HIV-1 proviruses, where continuous viral production and reactivation of transcription from these reservoirs are not affected by current drugs [1-4]. As such, novel classes of antivirals are needed to inhibit these processes. In this regard, a drug that blocks HIV transcription would be of great value because it offers the potential to shut down the transcription in HIV latent reservoirs.

SsnB was isolated from a Chinese herb, Spaganium stoloniferum $[5,6]$ and was recently reported to block TLR2 and TLR4 pathways [7]. Here we report that $\mathrm{SsnB}$ is a potent inhibitor of HIV infection. Specifically, we performed a dose response experiment by treating HIV pNL4.3 infected CEM-SS cells with various doses of SsnB. Fourty eight hours post-infection we harvested supernatants and titered the infectivity

\footnotetext{
* Correspondence: Dr_JianLiang@163.com

Department of Infectious Diseases, Ruikang Hospital Affiliated to Guangxi University of Chinese Medicine, 10 Huadong Road, 530011 Nanning, Guangxi Province, China
}

on the indicator cell line TZM-bl [8]. It was observed that SsnB treatment reduced the infectivity of the supernatants by more than 10 fold (Fig. 1a). To expand our observation, we repeated the experiment using peripheral blood mononuclear cells (PBMCs). Similarly, increasing concentrations of $\mathrm{S} s \mathrm{~B}$ inhibited the production of HIV, measured by the release of p24 into the supernatants (Fig. 1b).

Next, we sought to determine if SsnB inhibits HIV1 transcription. To this end, we performed luciferase reporter assays. 293T cells were transfected by HIV-1 LTR-driven luciferase reporter constructs and then treated by SsnB at various concentrations. HEK293T cells in 24-well plates were transfected with $0.2 \mu \mathrm{g}$ reporter plasmid. $0.05 \mu \mathrm{g}$ pGL4.74[hRluc/TK] was included to control for transfection efficiency. Dual luciferase assay was performed. In support of our findings, SsnB treatment indeed inhibited the luciferase activity (Fig. 2a). Of note, HIV-1 LTR transcriptional activity was significantly increased upon phorbol myristate acetate (PMA) stimulation, whereas $\mathrm{SsnB}$ treatment reduced it by nearly 30 fold (Fig. 2a). To ensure that the observed effect was not due to the cytotoxicity of SsnB, we sought to determine the $\mathrm{CC}_{50}$ of the compound and found no cytotoxicity even at the highest concentration that was tested (Fig. 2b). 

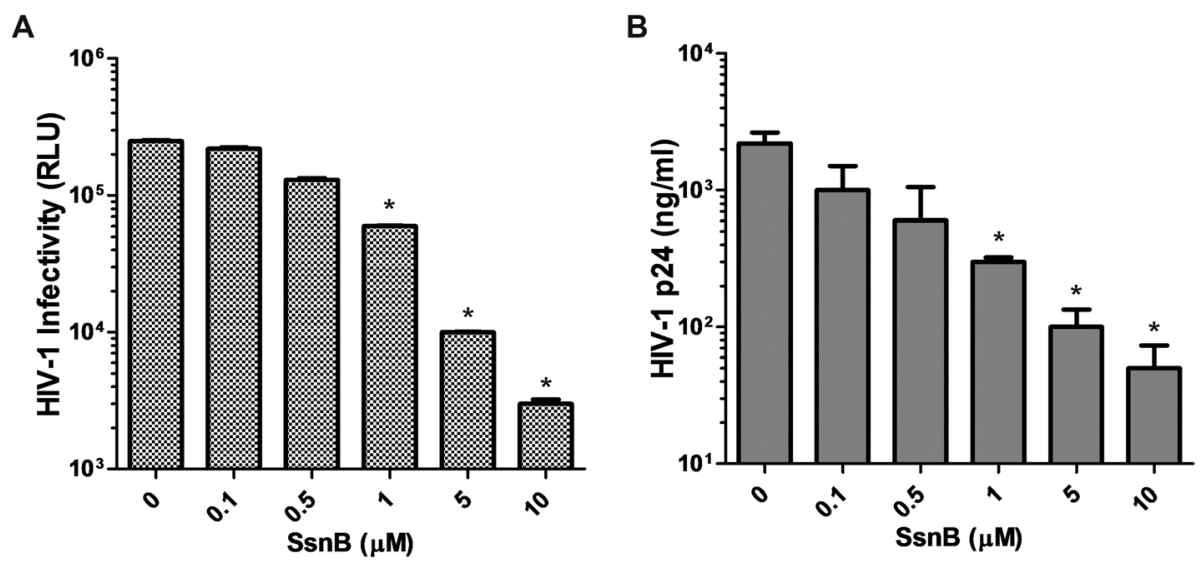

Fig. 1 SsnB inhibits HIV production. a CEM-SS cells were infected with HIV pNL4.3 (MOI 0.01) and then treated with SsnB at indicated concentrations for $12 \mathrm{~h}$. Newly released virus in the supernatants was collected $24 \mathrm{~h}$ after exposure to SsnB and then titered on the TZM-BI cells. ${ }^{*} p<0.01, n=4$. b PHA activated PMBCs were infected with pNL4.3 (MOI 0.1) for $5 \mathrm{~h}$ followed by SsnB treatment for $12 \mathrm{~h}$. After an additional $24 \mathrm{~h}$, the HIV p24 concentrations in the supernatants were determined by ELISA. ${ }^{*} p<0.01, \mathrm{n}=3$

To investigate the potential mechanism of inhibition, we generated successive deletion constructs by removing the two NF-B binding sites, three Sp1 binding sites, and the TAR region from HIV-1 LTR $[9,10]$ (Fig. 3a). All of these LTR fragments were synthesized at WuXi AppTec (China) and subcloned into the pGL4.11[luc2P] plasmid (Promega). We transfected 293T cells with these constructs and treated cells with SsnB. While the removal of the NF-kB or Sp1 binding sites has no effect on SsnB-mediated inhibition, the $\triangle$ TAR construct became non-responsive to $\mathrm{SsnB}$ treatment (Fig. 3b). To corroborate this finding, we cotransfected a minimal LTR-Luc construct containing the TAR region with a Tat expressing plasmid into 293T cells. In the presence of SsnB, Tat-induced LTR transcription was severely inhibited (Fig. 3c). Altogether, our results suggest that $\mathrm{SsnB}$ is inhibiting HIV transcription via a novel mechanism that requires the presence of TAR region. Of note, the $\triangle \mathrm{TAR}$ construct remained transcriptionally active, albeit at much lower efficiency, which is consistent with what has been reported recently [11]. The TAR region is very important for HIV Tatdependent transcriptional activation [12-14]. It would be interesting to test in the future whether SsnB exerts its inhibitory effect by directly interacting with TAR region or with TAR-region binding proteins such as HIV Tat or its cofactor. Further effort to identify cellular or viral targets of SsnB would be crucial in understanding the mechanism of SsnB-mediated blockage of HIV transcription.

Lastly, we tested whether SsnB is able to act synergistically with approved antivirals. To this end, we tested
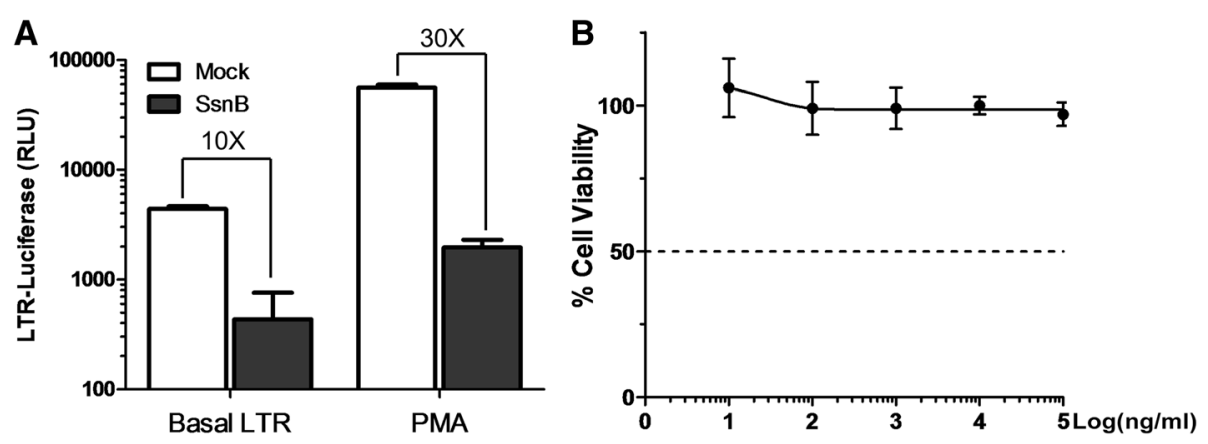

Fig. 2 SsnB inhibited HIV LTR promoter activity. a 293T cells were transfected with HIV LTR plasmid together with pGL4.74 [hRluc/TK]. Cells were either left unstimulated or stimulated with PMA $(50 \mathrm{ng} / \mathrm{ml})$ for $12 \mathrm{~h}$ followed by mock or SsnB $(1 \mu \mathrm{g} / \mathrm{ml}, \sim 3.7 \mu \mathrm{M})$ treatment for another $12 \mathrm{~h}$. Luciferase assay was performed. Normalized HIV LTR promoter activity was presented. b CEM-SS cells were treated with SsnB at various concentrations for $12 \mathrm{~h}$ and cell viability was determined by CellTiter Glo kit (Promega) $24 \mathrm{~h}$ after the initial exposure 


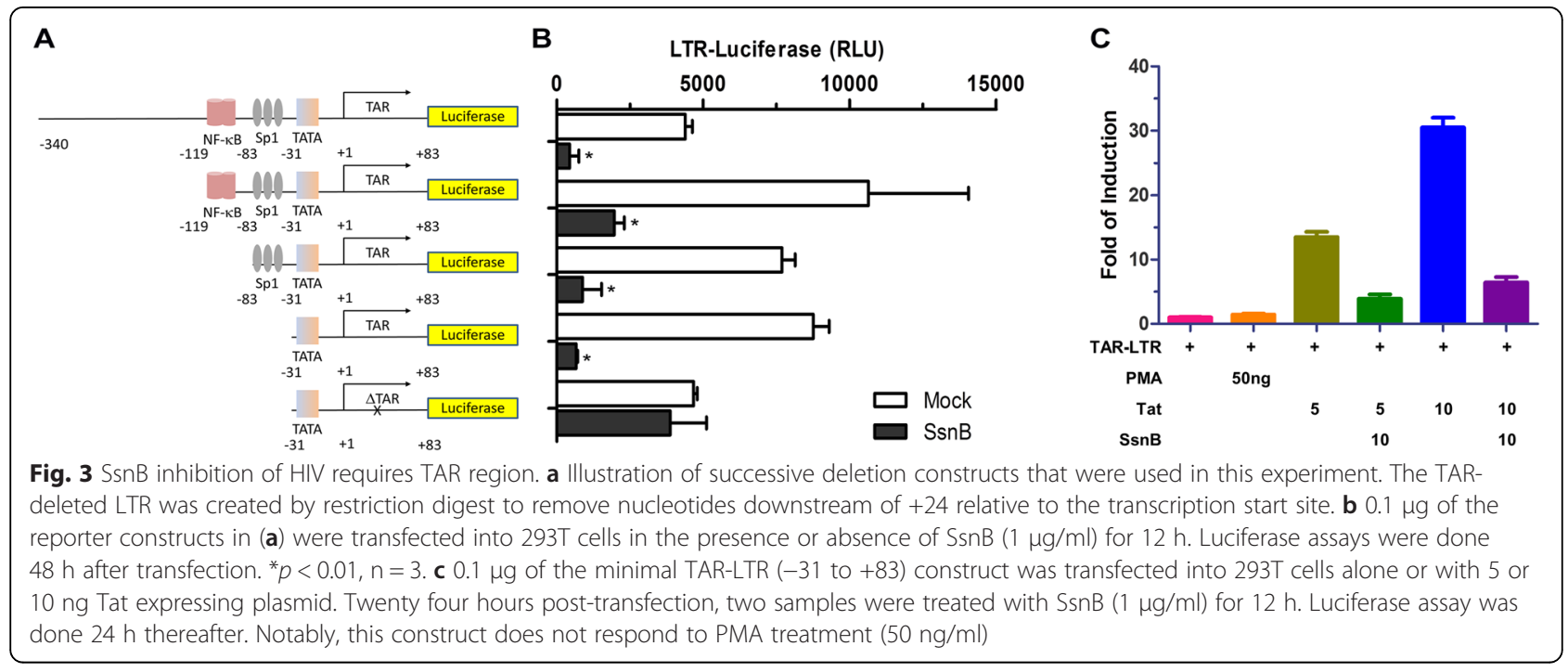

the $\mathrm{IC}_{50}$ of $\mathrm{SsnB}$ with the chain terminator of HIV replication, azidothymidine (AZT) [15]. Data from the drug combination experiments were analyzed according to theorem of Chou-Talalay $[16,17]$. In each experiment, the dose-effect data for each single agent and the combination were used to plot a median-effect curve [16, 17]. The derived curves are used for calculation of the combination index (CI) (Table 1) as described previously [18]. The resulting combination index (CI) offers quantitative definition for additive effect $(\mathrm{CI}=1)$, synergism $(\mathrm{CI}<1)$, and antagonism $(\mathrm{CI}>1)$ in drug combinations $[16,17]$. Shown in Table 1, SsnB displayed synergy with AZT when administered together. Altogether, our findings show that SsnB is a novel natural compound that exerts anti-HIV activity by suppressing HIV transcription through the TAR region. These exciting results warrant future studies in testing its effect in combination with other known HIV drugs. It is possible that SsnB may become a new class of anti-HIV drugs that is more affordable.

Table 1 Synergism between SsnB and AZT

\begin{tabular}{|c|c|c|c|c|c|c|}
\hline \multirow{2}{*}{$\begin{array}{l}\text { Expt } \\
\text { no. }\end{array}$} & \multicolumn{2}{|l|}{ Concentration of: } & \multicolumn{4}{|c|}{$\mathrm{Cl}$ at HIV-1 inhibition of: } \\
\hline & $\mathrm{AZT}(\mu \mathrm{M})$ & $\mathrm{SsnB}(\mu \mathrm{g} / \mathrm{ml})$ & $50 \%$ & $75 \%$ & $90 \%$ & $95 \%$ \\
\hline 1 & $0.04,0.16,0.64,1.28$ & $0.1,0.5,1,10$ & 0.87 & 0.63 & 0.47 & 0.38 \\
\hline 2 & $0.0025,0.005,0.01,0.02$ & $0.5,1,10,50$ & 0.77 & 0.53 & 0.46 & 0.43 \\
\hline
\end{tabular}

$0.5 \times 10^{6} / \mathrm{ml}$ CEM-SS cells were exposed to pNL4.3 virus (p24 100 ng) as inoculum in flasks containing either single agent (four concentrations each) or four combinations of AZT and SsnB (for example, in Exp 1, $0.04 \mu \mathrm{M}$ AZT + $0.1 \mu \mathrm{g} / \mathrm{ml} \mathrm{SsnB} ; 0.16 \mu \mathrm{M}$ AZT $+0.5 \mu \mathrm{g} / \mathrm{ml}$ SsnB, and so on) for $12 \mathrm{~h}$. Fourty eight hours thereafter, the production of infectious virus in the supernatants was determined by the standard TZM-bl assay [8]. The calculation was done using the method described in $[18,19]$. Cls of $<1,1$, and $>1$ indicate synergism, additive effects, and antagonism, respectively.
Competing interests

The authors declare that they have no competing interests.

\section{Authors' contributions}

$J \mathrm{~L}$ and $X D$ designed the overall experiments; $X D, Y Z, F J, R C, P P, B W$ performed the experiments and analyzed the data; $X D$ and $J L$ wrote the manuscript. All authors read and approved the final manuscript.

\section{Acknowledgments}

This study was sponsored by National Natural Science Foundation of China Grant 2014DFA30580, The Ministry of Education of the People's Republic of China grant NCET-13-0745, Guangxi Science and Technology key projects 1298003-1-1, 1355006-7, and 14124004-2-2. J. L. is a Guangxi Bagui Scholar.

Received: 18 February 2015 Accepted: 3 July 2015

Published online: 25 July 2015

\section{References}

1. Zack JA, Arrigo SJ, Weitsman SR, Go AS, Haislip A, Chen IS. HIV-1 entry into quiescent primary lymphocytes: molecular analysis reveals a labile, latent viral structure. Cell. 1990;61(2):213-22.

2. Bukrinsky MI, Stanwick TL, Dempsey MP, Stevenson M. Quiescent T lymphocytes as an inducible virus reservoir in HIV-1 infection. Science. 1991;254(5030):423-7.

3. McDougal JS, Mawle A, Cort SP, Nicholson JK, Cross GD, SchepplerCampbell JA, et al. Cellular tropism of the human retrovirus HTLV-III/LAV. I. Role of T cell activation and expression of the T4 antigen. J Immunol. 1985;135(5):3151-62.

4. Ganesh L, Burstein E, Guha-Niyogi A, Louder MK, Mascola JR, Klomp LW, et al. The gene product Murr1 restricts HIV-1 replication in resting CD4+ lymphocytes. Nature. 2003;426(6968):853-7. doi:10.1038/nature02171.

5. Qiu C, Xu X. H. Z. Pharmacology and clinics of Chinese material. Medica. 2008;14.

6. Lee SY, Choi SU, Lee JH, Lee DU, Lee KR. A new phenylpropane glycoside from the rhizome of Sparganium stoloniferum. Arch Pharm Res. 2010;33(4):515-21. doi:10.1007/s12272-010-0404-1.

7. Liang Q, Wu Q, Jiang J, Duan J, Wang C, Smith MD, et al. Characterization of sparstolonin B, a Chinese herb-derived compound, as a selective Toll-like receptor antagonist with potent anti-inflammatory properties. J Biol Chem. 2011;286(30):26470-9. doi:10.1074/jbc.M111.227934.

8. Wei X, Decker JM, Liu H, Zhang Z, Arani RB, Kilby JM, et al. Emergence of resistant human immunodeficiency virus type 1 in patients receiving fusion inhibitor (T-20) monotherapy. Antimicrob Agents Chemother. 2002;46(6):1896-905. 
9. Garcia JA, Harrich D, Soultanakis E, Wu F, Mitsuyasu R, Gaynor RB. Human immunodeficiency virus type 1 LTR TATA and TAR region sequences required for transcriptional regulation. Embo J. 1989;8(3):765-78.

10. Southgate CD, Green MR. The HIV-1 Tat protein activates transcription from an upstream DNA-binding site: implications for Tat function. Genes Dev. 1991;5(12B):2496-507.

11. Shridhar V, Chen Y, Gupta P. The CD8 antiviral factor (CAF) can suppress HIV-1 transcription from the long terminal repeat (LTR) promoter in the absence of elements upstream of the CATATAA box. Virol J. 2014;11:130. doi:10.1186/1743-422X-11-130.

12. Dingwall C, Ernberg I, Gait MJ, Green SM, Heaphy S, Karn J, et al. Human immunodeficiency virus 1 tat protein binds trans-activation-responsive region (TAR) RNA in vitro. Proc Natl Acad Sci U S A. 1989;86(18):6925-9.

13. Weeks KM, Ampe C, Schultz SC, Steitz TA, Crothers DM. Fragments of the HIV-1 Tat protein specifically bind TAR RNA. Science. 1990;249(4974):1281-5.

14. Roy S, Delling U, Chen CH, Rosen CA, Sonenberg N. A bulge structure in HIV-1 TAR RNA is required for Tat binding and Tat-mediated transactivation. Genes Dev. 1990;4(8):1365-73.

15. Broder $\mathrm{S}$. The development of antiretroviral therapy and its impact on the HIV-1/ AIDS pandemic. Antiviral Res. 2010;85(1):1-18. doi:10.1016/j.antiviral.2009.10.002.

16. Chou TC. Drug combination studies and their synergy quantification using the Chou-Talalay method. Cancer Res. 2010;70(2):440-6. doi:10.1158/0008-5472.CAN-09-1947.

17. Greco WR, Bravo G, Parsons JC. The search for synergy: a critical review from a response surface perspective. Pharmacol Rev. 1995;47(2):331-85.

18. Chou TC, Talalay P. Quantitative analysis of dose-effect relationships: the combined effects of multiple drugs or enzyme inhibitors. Adv Enzyme Regul. 1984;22:27-55.

19. Eron Jr JJ, Johnson VA, Merrill DP, Chou TC, Hirsch MS. Synergistic inhibition of replication of human immunodeficiency virus type 1 , including that of a zidovudine-resistant isolate, by zidovudine and 2',3'-dideoxycytidine in vitro. Antimicrob Agents Chemother. 1992;36(7):1559-62.

\section{Submit your next manuscript to BioMed Central and take full advantage of:}

- Convenient online submission

- Thorough peer review

- No space constraints or color figure charges

- Immediate publication on acceptance

- Inclusion in PubMed, CAS, Scopus and Google Scholar

- Research which is freely available for redistribution 